Journal of Clinical Investigation

Vol. 42, No. 7, 1963

\title{
THE ROLE OF ENDOTOXIN DURING TYPHOID FEVER AND TULAREMIA IN MAN. I. ACQUISITION OF TOLERANCE TO ENDOTOXIN *
}

\author{
By SHELDON E. GREISMAN, $\dagger$ RICHARD B. HORNICK, FRANK A. CAROZZA, JR., \\ AND THEODORE E. WOODWARD \\ (From the Departments of Medicine and Physiology, University of Maryland School of Medi- \\ dicine, Baltimore, $M d$.)
}

(Submitted for publication January 16, 1963; accepted March 7, 1963)

Endotoxins prepared from gram-negative bacteria induce profound physiologic derangements in man (1), yet their clinical significance during illnesses induced by gram-negative bacteria is speculative. One major objection to ascribing any significant role to endotoxin in mediating the pathophysiologic changes of infection is based on the phenomenon of acquired tolerance. Whenever endotoxin is administered daily to man as single iv injections, resistance to the toxic and pyrogenic activities develops rapidly (2). Such acquisition of tolerance suggested to some investigators that circulating endotoxin plays no major role in those infections in which fever is sustained $(3,4)$. Nevertheless, tolerance to Brucella endotoxin is not acquired during brucellosis, a gramnegative infection occasionally characterized by a sustained febrile course. Indeed, since the infected human host hyperreacts to this material, Spink suggested in 1954 that Brucella endotoxin contributes significantly to pathogenesis (5).

Endotoxin has also been regarded as a prime pathogenic factor in typhoid fever. In 1898, Mallory concluded, "The typhoid bacillus produces a mild diffusible toxine, partly within the intestinal tract, partly within the blood and organs of the body. This toxine produces proliferation of en: dothelial cells which acquire for a certain length of time malignant properties. The new formed cells are epithelioid in character ... and are characterized by marked phagocytic properties

* This study was supported by the Commission on Epidemiological Survey of the Armed Forces Epidemiological Board and the International Center for Medical Research and Training Program, U. S. Public Health Service research grant E 4162.

$\dagger$ Recipient of Career Development Award from the National Institutes of Health under contract HE-K3-15, 237-C1.
(6)." Subsequent data suggest that Salmonella typhosa endotoxin may induce other features of typhoid illness. This evidence, based largely upon the striking clinical similarities of host alterations during typhoid fever and those observed after iv administration of purified $S$. typhosa endotoxin, has been reviewed recently (7). This review stresses the circumstantial nature of clinical evidence and the need for definitive data on the role of endotoxin.

Since 1959, we have attempted to detect physiologically active quantities of circulating endotoxin during gram-negative bacterial infections in man. These investigations were initiated after successful development of a reproducible model of typhoid fever in volunteer subjects during studies evaluating the efficacy of typhoid vaccines. Observations of a variety of physiologic parameters in the same subject before, during, and after infection provided a unique opportunity to examine the evidence that endotoxin contributes to pathogenesis. Since the phenomenon of tolerance represents a characteristic and reproducible response to repeated exposure to circulating endotoxin, the initial studies were conducted to determine whether tolerance is acquired following typhoid fever. Parallel studies were carried out during infection induced with Pasteurella tularensis, since this agent possesses endotoxin and produces clinical manifestations similar to typhoidal infections. Control studies were performed employing the agent of sandfly fever, which provokes an infectious disease in which endotoxin presumably does not participate.

\section{MATERIALS AND METHODS}

Volunteers for these studies were male inmates of the Maryland House of Correction, Jessup, Md., whose ages ranged from 22 to 52 . Each volunteer was fully ap- 


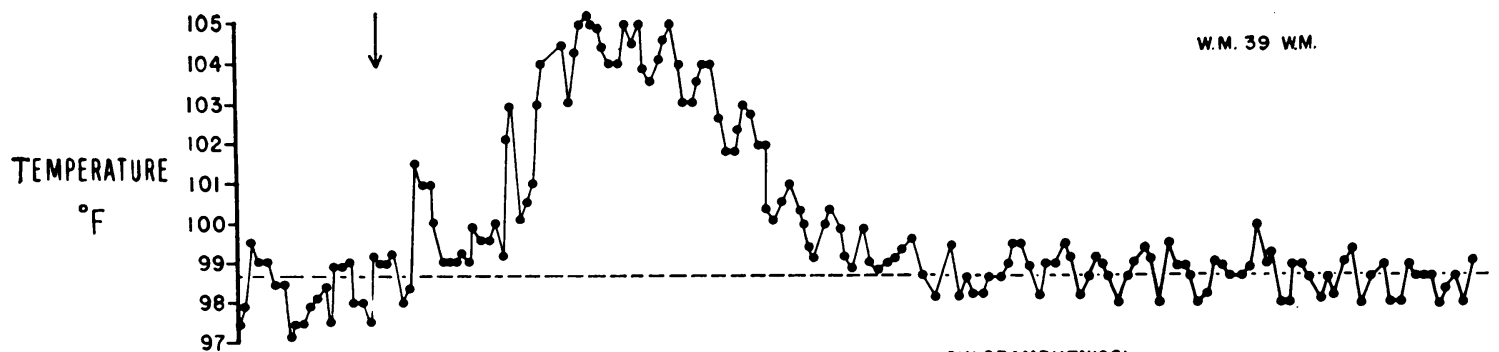
CHLORAMPHENICOL

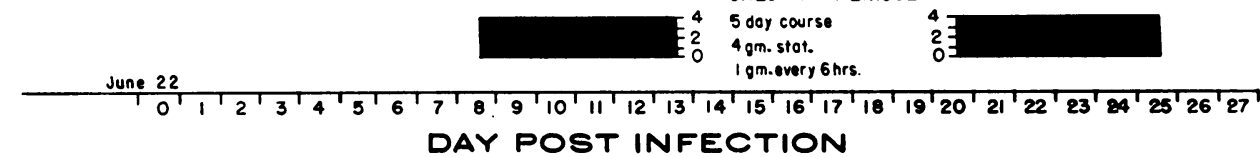
DAY POST INFECTION

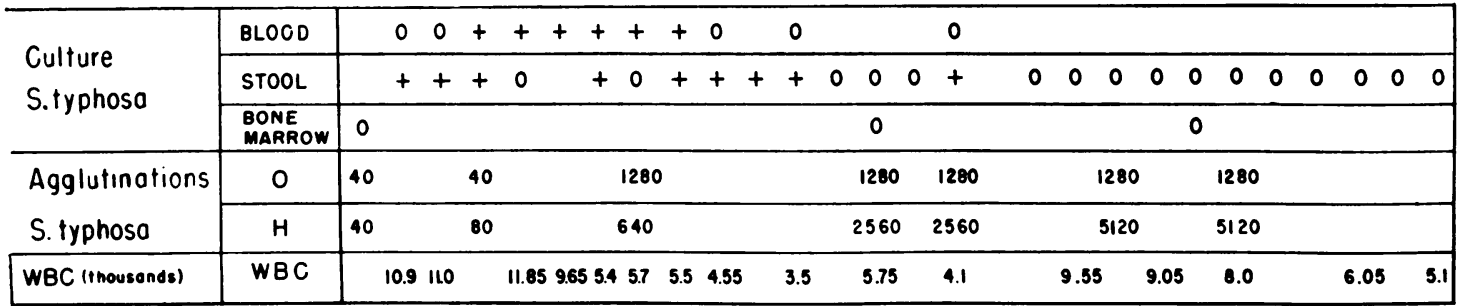

Fig. 1. Typical pattern of the febrile course of induced typhoid fever. Viable Salmonella typhosa administered orally at time indicated by arrow.

prised of all aspects of the investigation and the attendant risk. They were free to cease participation at any time. Complete medical surveys were performed to verify the fitness of each participant.

\section{Infectious agents and nature of clinical illness.}

Typhoid fever. Details of the preparation and administration of the inocula of $S$. typhosa used to induce typhoidal infection will be presented elsewhere (8). The "Quailes" strain of $S$. typhosa, which is a phage D-1 type containing $\mathrm{Vi}$ antigen but which is $\mathrm{O}$ agglutinable was used. Varying infecting doses were employed. Illness was regularly produced following ingestion of $1 \times 10^{7}$ to $1 \times 10^{9}$ organisms. Figure 1 depicts the febrile course in a typical subject. The onset of fever was generally accompanied by headache, abdominal pain, arthralgia, anorexia, and malaise. Blood and stools were cultured frequently to aid in verification and control of the disease. After an average of 48 hours of illness, each patient was treated with chloramphenicol, 13 to $4 \mathrm{~g}$ daily for 5 days. After one week without drug, an additional $3 \mathrm{~g}$ of chloramphenicol daily for 5 days completed the usual therapeutic course.

Tularemia. Tularemia was induced either aerogenically ${ }^{2}$ or by intradermal inoculation. Strain SCHU-S4

1 Chloromycetin, generously supplied by Parke, Davis \& Co., Detroit, Mich.

2 Aerosol exposures were performed by Mr. William Griffith and associates, Aerobiology Division, Fort Detrick, Md. of $P$. tularensis ${ }^{3}$ was used in all instances. Complete data will be given elsewhere (9). Volunteers received an intradermal injection of 1,000 human infectious doses. After 24 hours, a faint localized erythematous macule appeared, which in 48 hours became an indurated papule $2 \mathrm{~cm}$ in diameter. The erythema extended although the papule remained unchanged. Fever developed about day 3 accompanied by systemic symptoms, predominantly headache and chilliness. Central necrosis of the papule usually occurred on day 4, followed by formation of a black eschar. Lymph nodes in the epitrochlear and axillary areas draining the lesion enlarged on day 5 and continued to enlarge rapidly during the subsequent 2 days. After 36 hours of fever, streptomycin therapy was initiated in a dose of $2 \mathrm{~g}$ daily intramuscularly. This produced dramatic relief of symptoms, lysis of fever, and gradual healing of the local lesion with regression of the regional lymph nodes.

Resipartory tularemia became clinically apparent after a 3- to 5-day incubation period, with fever, headache, substernal pain, nonproductive, hacking cough, and backache. Streptomycin, employed in most infected volunteers, controlled the infection promptly.

Sandfly fever. Sandfly fever was induced by iv administration of plasma collected during the acute phase of disease from previously infected volunteers. ${ }^{4}$ Plasma

${ }^{3}$ Kindly prepared and supplied by Dr. Henry Eigelsbach, Microbiology Division, Fort Detrick, Md.

4 The original stock plasma containing the Sicilian strain of this virus was kindly supplied by Dr. Benjamin Sweet. 
for volunteers was preserved at $-70^{\circ} \mathrm{C}$ and thawed immediately before administration. After an incubation period of 3 days, illness was heralded by sudden rise in temperature, frontal headache, retroorbital pain, backache, myalgia, and anorexia. Physical findings included vesicles on the soft palate, conjunctival injection, and erythematous flushing of the face and neck during the febrile period. Fever usually persisted for 2 to 3 days, and as the fever waned, clinical improvement rapidly developed.

\section{Bacterial endotoxins}

Two preparations of bacterial endotoxin were employed for assay of endotoxin tolerance, a highly purified endotoxin of $S$. typhosa (O-282), 5 previously described (10), and Escherichia coli endotoxin (Difco, 0127B8), ${ }^{6}$ prepared by a modified Boivin method (11). Both endotoxin preparations were suspended in sterile, pyrogenfree, physiologic saline and stored in rubber-stoppered vaccine bottles at $4^{\circ} \mathrm{C}$. The $S$. typhosa endotoxin was diluted to a concentration of $0.5 \mu \mathrm{g}$ per $\mathrm{ml}$ and the $E$. coli endotoxin to $1.0 \mu \mathrm{g}$ per $\mathrm{ml}$. The same bottle of diluted endotoxin was employed throughout any given study. All syringes and glassware were heated overnight in a dry-air oven at $180^{\circ} \mathrm{C}$ to eliminate extraneous pyrogens. The diluted endotoxin preparations were bacteriologically sterile. Potency of the diluted endotoxins was tested

${ }^{5}$ Kindly supplied by Dr. Maurice Landy, National Institutes of Health, Bethesda, Md.

${ }^{6}$ Difco Laboratories, Detroit, Mich. prior to the human studies by a standard pyrogen assay procedure employing acclimatized, loosely restrained, albino rabbits. Repeat assays conducted at the conclusion of the studies, in groups of four rabbits each, with two dose levels for each group (0.05 and $0.005 \mu \mathrm{g}$ per kilogram rabbit weight), indicated no loss of pyrogenicity.

\section{Pyrogen assay in man}

Volunteers were hospitalized before the induction of typhoid fever, tularemia, or sandfly fever. All responses to endotoxin were assayed after the subjects were confined to bed and covered with a light blanket. Each test was begun between 8 and 9 a.m. Flexible thermocouples were inserted into the rectum for fixed distances (6 inches), and temperatures recorded by a Telethermometer. ${ }^{7}$ Temperatures were monitored immediately before and every half-hour after the iv injection of endotoxin. The results were plotted on standard graph paper, and the area under the 7-hour fever curve, with the initial temperature as the base line, was calculated by summing the number of enclosed small squares. This value, termed the fever index, represents a measure of the height and duration of the febrile response (12). The ordinates were plotted so that 100 squares represented a fever index of 100 and reflected a $1^{\circ} \mathrm{F}$ rise in rectal temperature for a 1-hour duration. The diurnal variation of normal body temperature was so great that tempera-

${ }^{7}$ Supplied by Yellow Springs Instrument Co., Yellow Springs, Ohio.

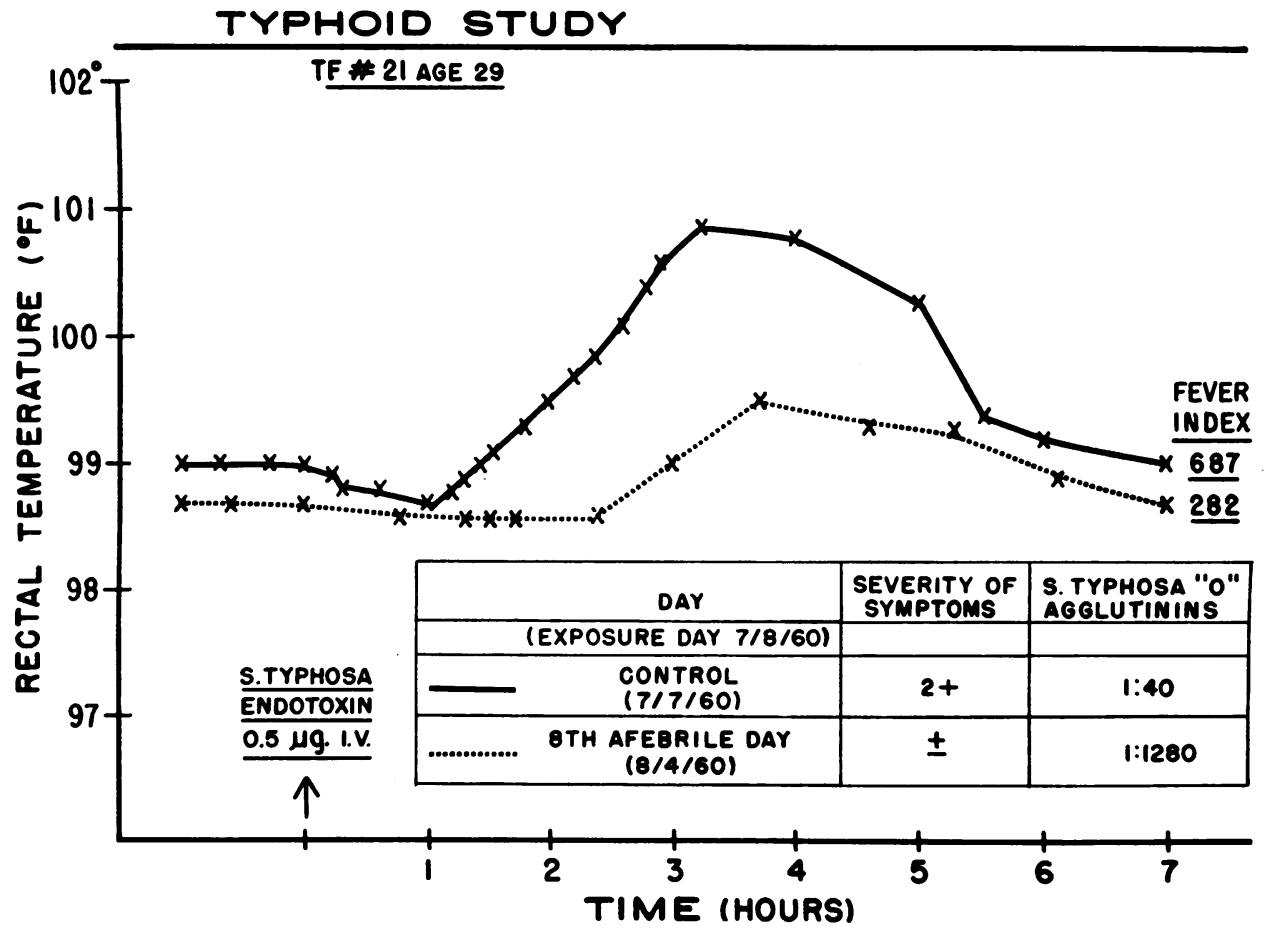

Fig. 2. Febrile Response pattern following iv INJection of $S$. typhosa endotoxin before AND ON CONVALESCENT DAY 8 AFTER INDUCED TYPHOID FEVER. 


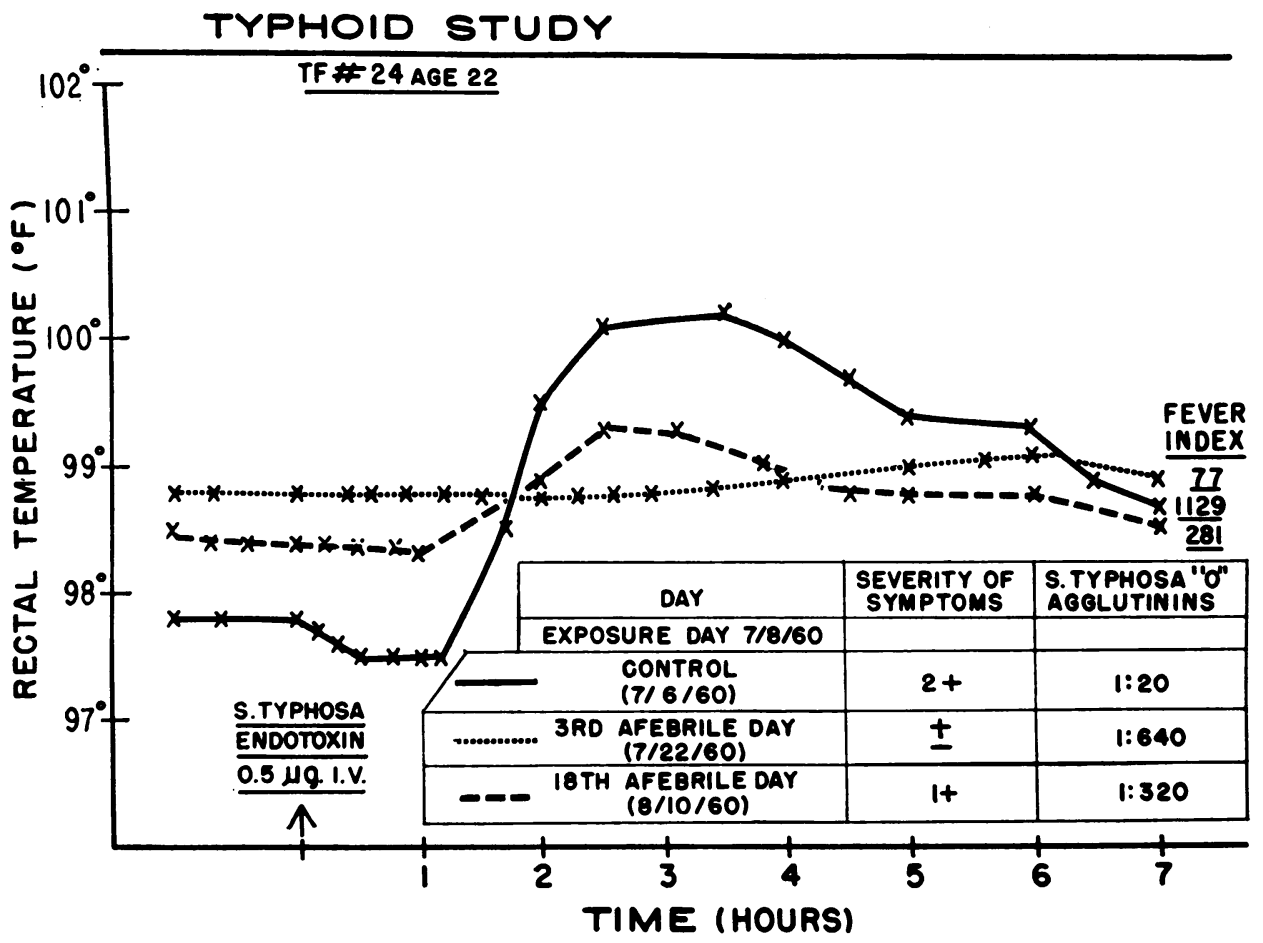

Fig. 3. Febrile RESPONSE PATtern following iv injection of $S$. typhosa endotoxin before AND ON CONVALESCENT DAYS 3 AND 18 AFTER INDUCED TYPHOID FEVER.

\section{TYPHOID STUDY}

\section{T.F. \# 14 AGE 49}

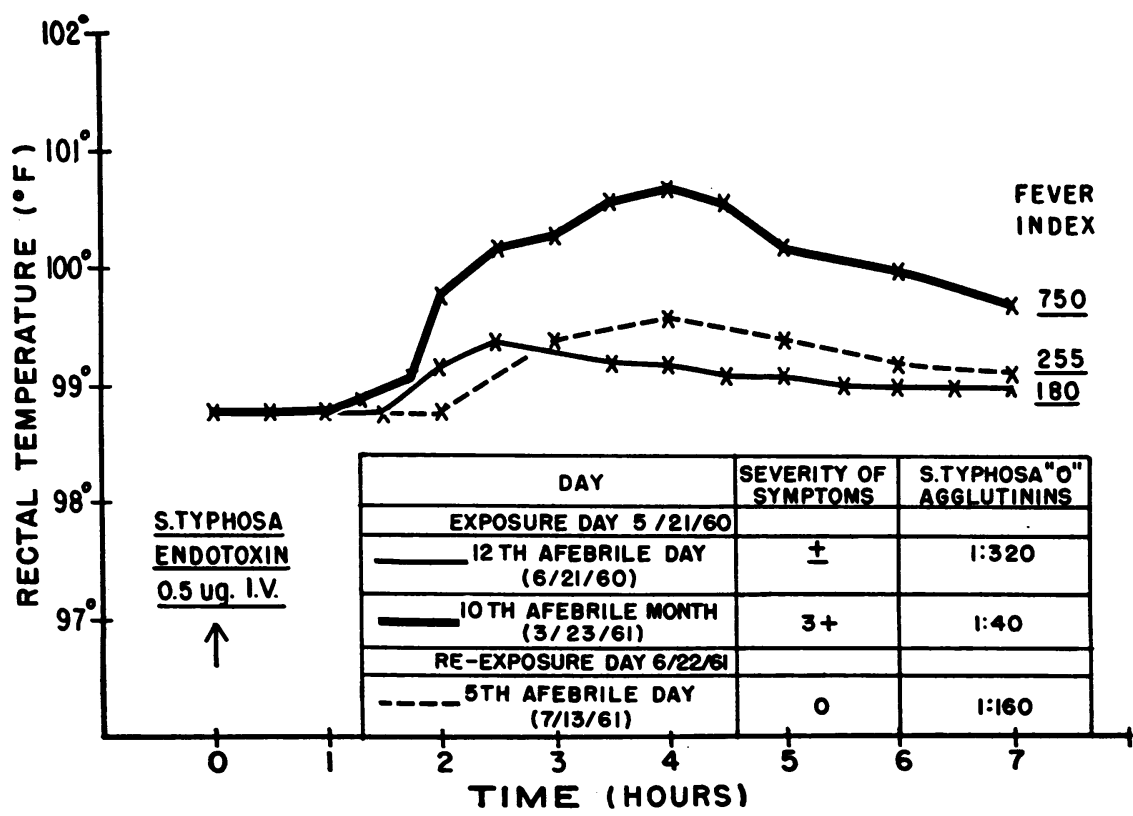

Fig. 4. Febrile response pattern following iv injection of S. typhosa endoTOXIN 12 DAYS AND 10 MONTHS AFTER CONVALESCENCE FROM INDUCED TYPHOID FEVER, AND 5 DAYS AFTER CONVALESCENCE FROM A SECOND COURSE OF INDUCED TYPHOID FEVER. 
ture seldom returned to preinjection values. In such instances, the fever curves were extrapolated to the base line.

After control responses to pyrogen were obtained, each subject was infected with one of the viable infectious agents. Responses to injection of the same endotoxin were reassayed at various periods during convalescence. In addition to the fever index, subjective reactions (headache, chills, myalgia, anorexia) following endotoxin administration were graded as follows: $1+=$ minimal, $2+=$ moderate, $3+=$ severe, and $4+=$ extremely severe.

\section{RESULTS}

Acquisition of tolerance to endotoxin following typhoid fever. Two volunteers were given single iv injections of $0.5 \mu \mathrm{g} S$. typhosa endotoxin before induced typhoid fever and again during convalescence. The reaction patterns are shown in Figures 2 and 3 . In each case, the fever index upon testing during afebrile days 3 to 8 was less than $50 \%$ that of the initial control value. In Subject TF (typhoid fever) no. 24 (Figure 3), repeat testing on afebrile day 18 revealed that tolerance was waning. A third volunteer in the typhoid series was tested initially with $0.5 \mu \mathrm{g} S$. typhosa endotoxin on convalescent day 12 (Figure 4). A reaction of tolerance is readily apparent, since repeat testing 10 months later revealed that the fever index had increased over fourfold. This subject was subsequently rechallenged with viable $S$. typhosa and again developed overt typhoid fever. Upon retesting with $0.5 \mu \mathrm{g} S$. typhosa endotoxin on afebrile day 5 , tolerance comparable to that following the initial bout of typhoid fever was again apparent. In general, the intensity of the subjective discomfort following $S$. typhosa endotoxin injection paralleled the height of the fever index in any given subject.

Two additional subjects were tested with single iv injections of $1.0-\mu \mathrm{g}$ doses of $E$. coli endotoxin before induced typhoid fever and again during convalescence. ${ }^{8}$ The reaction patterns are shown

8 In the dosages employed, the E. coli and S. typhosa endotoxins possessed comparable pyrogenic potency, elicited parallel tolerance patterns upon daily iv injections, and produced marked cross-tolerance in groups of normal rabbits.

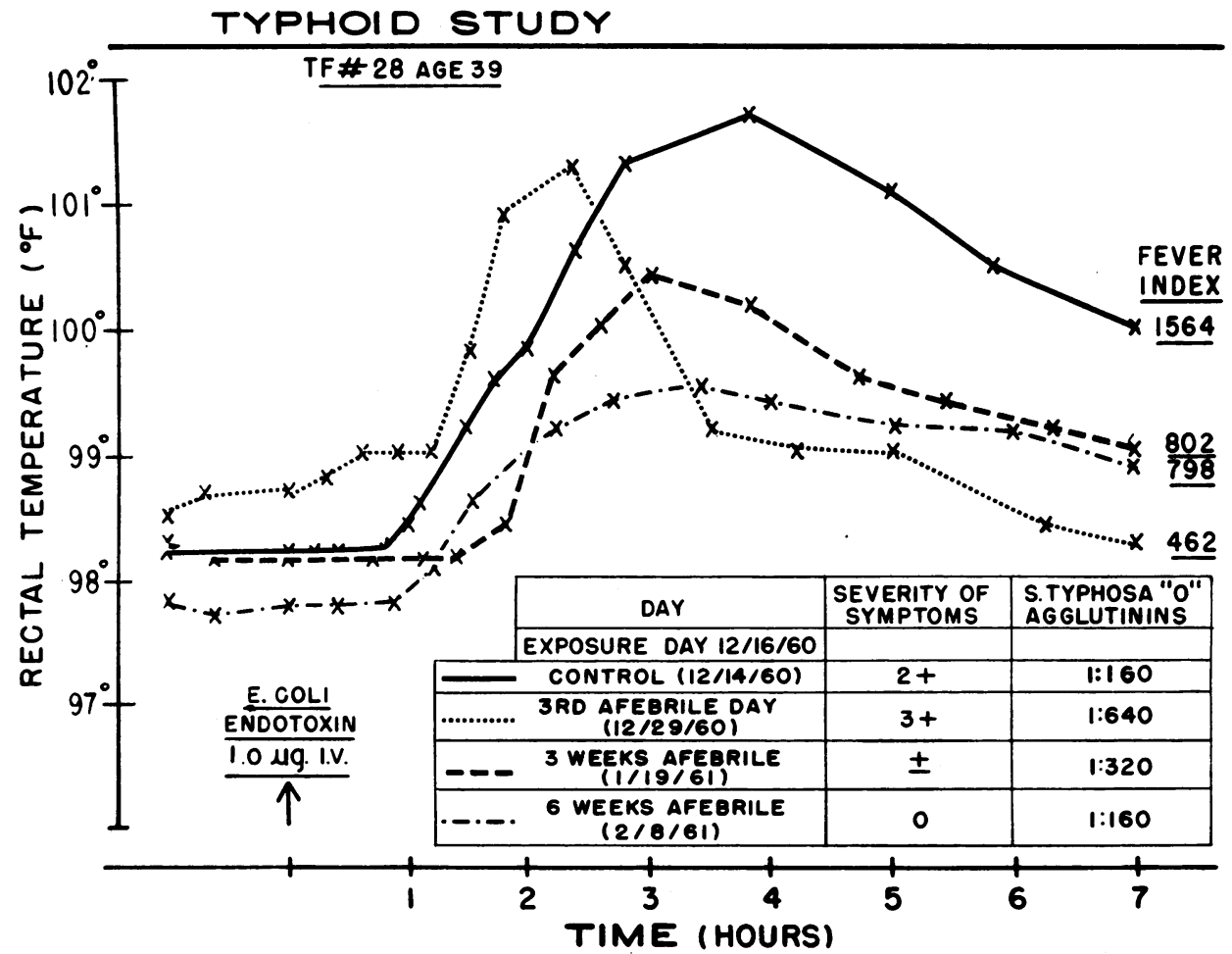

Fig. 5. Febrile Response pattern following iv injection of Escherichia coli endoTOXIN BEFORE AND ON DAY 3 AND DURING WEEKS 3 TO 6 OF CONVALESCENCE FROM INDUCED TYPHOID FEVER. 


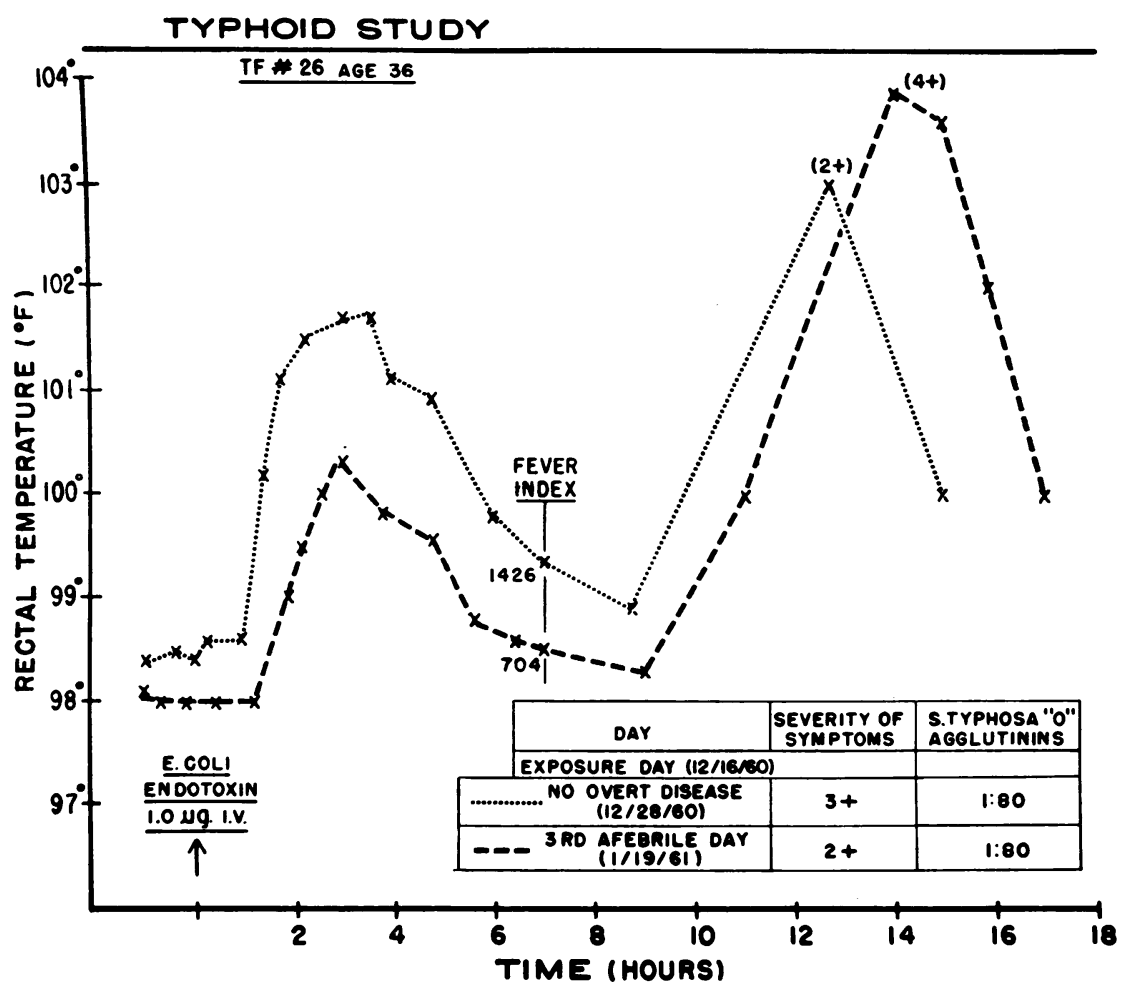

Fig. 6. FEBRILE RESPONSE PATTERN FOLLOWING IV INJECTION OF Escherichia coli ENDoTOXIN BEFORE AND ON CONVALESCENT DAY 3 AFTER INDUCED TYPHOID FEVER.

in Figures 5 and 6. The reactions simulated those Repeat testing in Subject TF no. 28 (Figure 5) resulting from $S$. typhosa endotoxin, and the fever revealed loss of pyrogenic tolerance as convalesindexes during afebrile day 3 of convalescence cence advanced, and after 12 weeks of convaleswere less than $50 \%$ of the initial control values. cence (not shown in Figure 5), the fever index had

TABLE I

Effect of induced typhoid fever $(T F)$ on responsiveness to iv administration of $0.5 \mu \mathrm{g}$ Salmonella typhosa endotoxin and $1.0 \mu \mathrm{g}$ Escherichia coli endotoxin

\begin{tabular}{|c|c|c|c|c|c|c|}
\hline \multirow[b]{2}{*}{$\begin{array}{l}\text { Subject } \\
\text { TF no. }\end{array}$} & \multirow[b]{2}{*}{ Age } & \multicolumn{2}{|c|}{ Control phase } & \multicolumn{2}{|c|}{ Convalescent phase $\|$} & \multirow{2}{*}{ 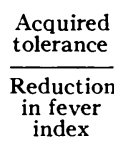 } \\
\hline & & $\begin{array}{l}\text { Fever } \\
\text { index }\end{array}$ & $\begin{array}{l}\text { Severity of } \\
\text { symptoms }\end{array}$ & $\begin{array}{l}\text { Fever } \\
\text { index }\end{array}$ & $\begin{array}{l}\text { Severity of } \\
\text { symptoms }\end{array}$ & \\
\hline & yrs & & & & & $\%$ \\
\hline 14 & 49 & $750^{*}$ & $3+$ & $\begin{array}{l}180 \\
255 \S\end{array}$ & \pm & $\begin{array}{l}76 \\
66\end{array}$ \\
\hline $\begin{array}{l}21 \\
24 \\
26 \\
28\end{array}$ & $\begin{array}{l}29 \\
22 \\
36 \\
39\end{array}$ & $\begin{array}{r}687^{*} \\
1,129^{*} \\
1,426 \dagger \\
1,564 \dagger\end{array}$ & $\begin{array}{l}2+ \\
3+ \\
3+ \\
2+\end{array}$ & $\begin{array}{c}282 \\
77 \\
704 \\
462\end{array}$ & $\begin{array}{l} \pm \\
\pm \\
2+ \\
3+\end{array}$ & $\begin{array}{l}59 \\
93 \\
51 \\
70\end{array}$ \\
\hline \multicolumn{2}{|c|}{$\begin{array}{l}\text { Mean } \\
\pm S E\end{array}$} & & & & & $\begin{array}{l}69 \\
6.1\end{array}$ \\
\hline
\end{tabular}

* S. typhosa endotoxin employed.

$\dagger E$. coli endotoxin employed.

‡ Subjective reactions after endotoxin administration were graded as follows: $1+=$ minimal, $2+=$ moderate $3+=$ severe, and $4+=$ extremely severe.

\$ Second course of typhoid fever.

II Afebrile days 3 to 12 . 
increased to 1,256 and the subjective reaction to 2+. Subject TF no. 26 (Figure 6) manifested a biphasic febrile reaction to endotoxin before typhoid illness and again during convalescence. Although the acquisition of tolerance during convalescence is apparent for the initial 7-hour febrile response, no tolerance is evident to the second delayed response. The explanation for this second febrile peak is unknown. As with the responses to $S$. typhosa endotoxin, the intensity of the subjective reactions generally paralleled the intensity of the febrile responses. The responses to endotoxin are summarized in Table I, and the degree of acquired tolerance is expressed as the percentage of reduction in fever index from initial control levels. An over-all reduction of fever index by $69 \%$ was observed following typhoid fever; $76 \%$ reduction occurred with $S$. typhosa endotoxin and $60 \%$ reduction with $E$. coli endotoxin.

Significance of acquired tolerance to endotoxin following typhoid fever. The acquisition of tolerance following typhoid fever, of the degree just described, could not be attributed to residual ef- fects of the initial control injection of endotoxin for the following reasons. 1) Two subjects were challenged with viable $S$. typhosa, but did not acquire overt typhoid illness. The reaction patterns to endotoxin in one of these subjects are shown in Figure 7. In neither subject was the fever index upon second testing below $10 \%$ of the initial control value. Indeed, Subject TF no. 27 (Figure 7) developed $S$. typhosa bacteremia and yet exhibited neither overt illness nor tolerance. Moreover, this subject manifested virtually identical febrile response patterns following repeated iv administration of single injections of $1.0-\mu \mathrm{g}$ quantities of $E$. coli endotoxin at intervals of several weeks. Only after $80 \mathrm{mg}$ of prednisone was given during 16 hours before challenge was the fever index reduced below $50 \%$ of the control value. 2 ) In the subjects shown in Figures 3 and 5, tolerance waned despite the repeated endotoxin administration. 3) In Subject TF no. 14 (Figure 4), tolerance was apparent when this subject was initially tested during the convalescent phase of typhoid fever. 4) Seven normal control subjects were given single iv injections of $S$. typhosa en-

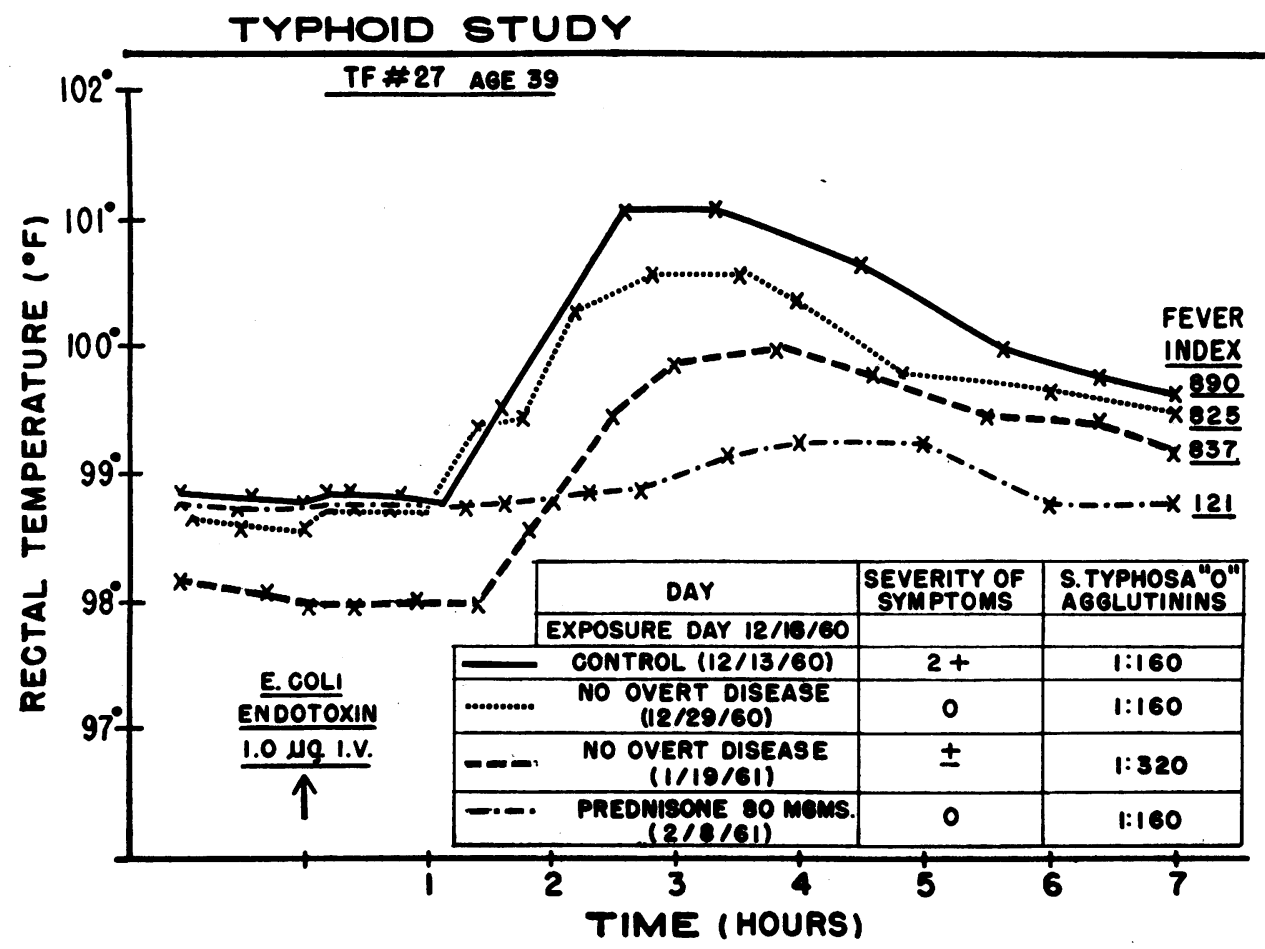

Fig. 7. Febrile response pattern following iv injection of Escherichia coli endotoxin BEFore AND After challenge with $10^{\circ}$ viable Salmonella typhosa. This subject did not develop overt typhoid illness, but did exhibit demonstrable bacteremia. 
TABLE II

Effect in control subjects $(\mathrm{CO})$ of two iv injections of $0.5 \mu \mathrm{g}$ of Salmonella typhosa endotoxin spaced at 1-week intervals

\begin{tabular}{|c|c|c|c|c|c|c|}
\hline \multirow[b]{2}{*}{$\begin{array}{l}\text { Subject } \\
\text { CO no. }\end{array}$} & \multirow[b]{2}{*}{ Age } & \multicolumn{2}{|c|}{ Injection 1} & \multicolumn{2}{|c|}{ Injection 2} & \multirow{2}{*}{ 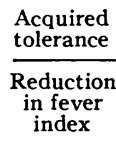 } \\
\hline & & $\begin{array}{l}\text { Fever } \\
\text { index }\end{array}$ & $\begin{array}{l}\text { Severity of } \\
\text { symptoms } \dagger\end{array}$ & $\begin{array}{l}\text { Fever } \\
\text { index }\end{array}$ & $\begin{array}{l}\text { Severity of } \\
\text { symptoms } \dagger\end{array}$ & \\
\hline $\begin{array}{l}1 \\
2 \\
3 \\
4 \\
5 \\
6 \\
7\end{array}$ & $\begin{array}{c}y r s \\
52 \\
23 \\
30 \\
42 \\
30 \\
36 \\
26\end{array}$ & $\begin{array}{r}1,205 \\
913 \\
814 \\
650 \\
948^{*} \\
1,127 \\
1,420\end{array}$ & $\begin{array}{l}2+ \\
2+ \\
1+ \\
1+ \\
2+ \\
2+ \\
3+\end{array}$ & $\begin{array}{r}1,035 \\
769 \\
771 \\
692 \\
317 \\
960 \\
927\end{array}$ & $\begin{array}{l}1+ \\
1+ \\
1+ \\
1+ \\
0 \\
1+ \\
2+\end{array}$ & $\begin{array}{r}\% \\
14 \\
16 \\
5 \\
-6 \\
67 \\
15 \\
34\end{array}$ \\
\hline $\begin{array}{l}\text { Mean } \\
\pm \text { SE }\end{array}$ & & & & & & $\begin{array}{l}21 \\
9.1\end{array}$ \\
\hline
\end{tabular}

* Shaking chill and febrile reaction for two successive mornings following initial reaction to endotoxin.

$\dagger$ See footnote to Table I.

dotoxin 1 week apart. The results are tabulated in Table II. The mean reduction in fever index attributable to the initial exposure to endotoxin was $21 \%$. In but one subject, $\mathrm{CO}$ (control) no. 5 , was the second fever index reduced below $50 \%$ of the original level. ${ }^{9}$ Four control subjects tested at

9 This subject was unique in that for two successive mornings following the initial iv injection of $S$. typhosa endotoxin, an abrupt rise in temperature of 1.5 to $2^{\circ} \mathrm{F}$ occurred, preceded by a shaking chill and frontal headache identical with the reactions on the morning of the endotoxin injection. a 14-day interval exhibited only a $10 \%$ mean reduction in initial fever index. After a 28- to 35day interval, even high degrees of tolerance induced by repeated daily iv injections of endotoxins are lost (2). Since the interval between endotoxin testing in the subjects given typhoid fever ranged from 12 to 112 days, with a mean of 35 days, it seems highly unlikely that the degree of tolerance developing after typhoid fever resulted simply from the initial injection of endotoxin ( $\mathrm{p}<0.005$ for $S$. typhosa endotoxin).

TABLE III

Effect of induced tularemia ( $T U$ ) on responsiveness to iv administration of $0.5 \mu \mathrm{g}$ Salmonella typhosa endotoxin

\begin{tabular}{|c|c|c|c|c|c|c|}
\hline \multirow[b]{2}{*}{$\begin{array}{l}\text { Subject } \\
\text { TU no. }\end{array}$} & \multirow[b]{2}{*}{ Age } & \multicolumn{2}{|c|}{ Control phase } & \multicolumn{2}{|c|}{ Convalescent phase $\S$} & \multirow{2}{*}{$\begin{array}{c}\begin{array}{c}\text { Acquired } \\
\text { tolerance }\end{array} \\
\begin{array}{c}\text { Reduction } \\
\text { in fever } \\
\text { index }\end{array}\end{array}$} \\
\hline & & $\begin{array}{l}\text { Fever } \\
\text { index }\end{array}$ & $\begin{array}{l}\text { Severity of } \\
\text { symptoms }\end{array}$ & $\begin{array}{l}\text { Fever } \\
\text { index }\end{array}$ & $\begin{array}{l}\text { Severity } \\
\text { of } \\
\text { symptoms }\end{array}$ & \\
\hline $\begin{array}{l}11^{*} \\
14^{*} \\
15^{*} \\
16^{*} \\
17^{*} \\
18^{*} \\
19^{*} \\
20^{*}\end{array}$ & $\begin{array}{l}y r s \\
29 \\
31 \\
33 \\
29 \\
25 \\
26 \\
37 \\
27\end{array}$ & $\begin{array}{r}823 \\
1,149 \\
913 \\
995 \\
490 \\
350 \\
1,249 \\
663\end{array}$ & $\begin{array}{l}2+ \\
2+ \\
1+ \\
3+ \\
2+ \\
0 \\
3+ \\
2+\end{array}$ & $\begin{array}{r}235 \\
701 \\
150 \\
648 \\
88 \\
288 \\
286 \\
462\end{array}$ & $\begin{array}{l}0 \\
0 \\
0 \\
0 \\
0 \\
0 \\
0 \\
0\end{array}$ & $\begin{array}{c}\% \\
72 \\
39 \\
84 \\
35 \\
82 \\
18 \\
77 \\
30\end{array}$ \\
\hline $\begin{array}{l}75 \dagger \\
76 \dagger \\
77 \dagger\end{array}$ & $\begin{array}{l}44 \\
42 \\
25\end{array}$ & $\begin{array}{l}928 \\
703 \\
886\end{array}$ & $\begin{array}{l}2+ \\
2+ \\
2+\end{array}$ & $\begin{array}{r}434 \\
160 \\
27\end{array}$ & $\begin{array}{l}0 \\
0 \\
0\end{array}$ & $\begin{array}{l}53 \\
77 \\
97\end{array}$ \\
\hline $\begin{array}{l}\text { Mean } \\
\pm S E\end{array}$ & & & & & & $\begin{array}{l}60 \\
13.9\end{array}$ \\
\hline
\end{tabular}

* Tularemia induced by intradermal challenge with Pasteurella tularensis.

$\dagger$ Tularemia induced by aerosol challenge with $P$. tularenesis.

$¥$ See footnote to Table I.

\$ Afebrile days 3 to 8 . 
TABLE IV

Effect of induced sandfly fever $(S F)$ on responsiveness to intravenous administration of $0.5 \mu \mathrm{g}$ of Salmonella typhosa endotoxin

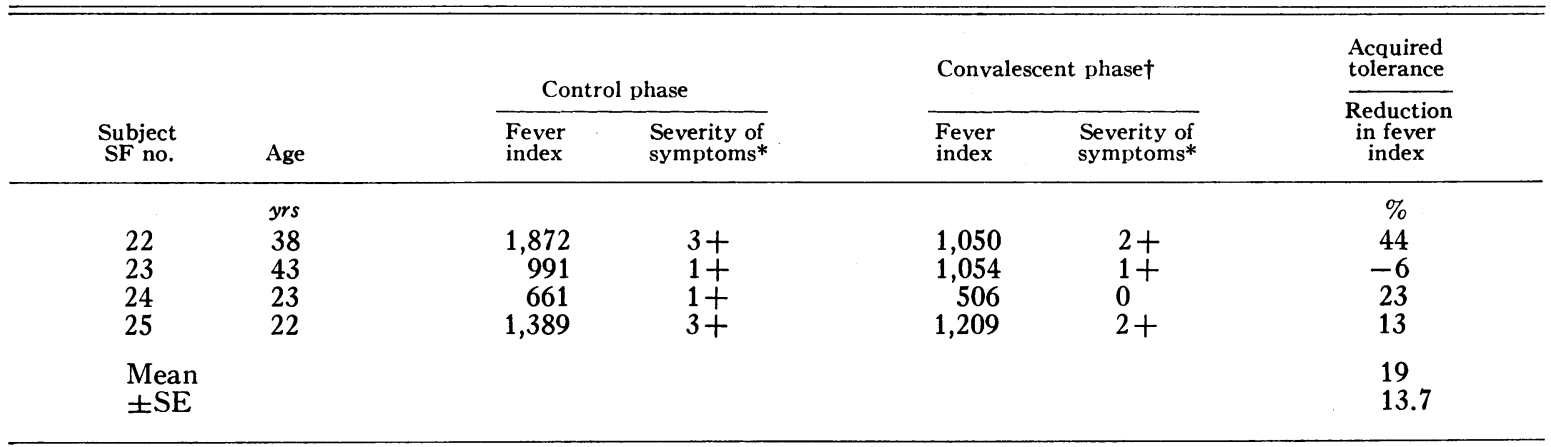

* See footnote to Table I.

$\dagger$ Afebrile days 4 to 5 .

The acquisition of tolerance to endotoxin following typhoid fever could not be attributed to the antibiotic employed for therapy. Febrile responses to $0.5-\mu \mathrm{g}$ doses of $S$. typhosa endotoxin were monitored in two subjects in whom tolerance had lapsed after convalescence from typhoid fever for 5 and 12 months, respectively. They were then given chloramphenicol in a dosage and manner identical to that previously employed during typhoid fever. Repeat testing with endotoxin following completion of "therapy" revealed less than $10 \%$ decrease in fever index in both subjects. In addition, the one subject ( $\mathrm{TF}$ no. 14) who developed overt typhoid fever and did not require therapy acquired a high degree of tolerance to endotoxin.

From the data described it is apparent that the reductions of $50 \%$ or more in fever indexes, developing uniformly after typhoid fever, were not attributable to the initial endotoxin testing or to chloramphenicol therapy, but represented an effect of infection per se.

Specificity of acquired tolerance to endotoxin following typhoid fever. To determine whether infectious illnesses other than typhoid fever conferred tolerance in man, endotoxin responses were monitored before and after induced tularemia and sandfly fever. In 11 subjects given tularemia, the fever indexes and subjective reactions were monitored after administration of $0.5 \mu \mathrm{g}$ of $S$. typhosa endotoxin. The results are shown in Table III. The mean reduction in fever index on afebrile convalescent days 3 to 8 was $60 \%$ of the initial control level. When this value is compared with that of the normal control subjects, it is unlikely $(\mathrm{p}<0.05)$ that this degree of tolerance could be attributed to the initial testing with endotoxin. Moreover, two other subjects failed to develop overt illness after attempts to infect. When such subjects were tested with endotoxin at intervals comparable to the previous group, the fever indexes were reduced in both cases by less than $13 \%$ of the initial control values.

In sharp contrast to the findings in typhoid fever and tularemia, subjects convalescing from sandfly fever acquired no tolerance to the pyrogenic action of $S$. typhosa endotoxin other than that which could be accounted for simply by the residual effect of the initial control testing. Table IV illustrates the fever indexes and subjective reactions of four volunteers following the iv administration of $0.5 \mu \mathrm{g}$ of $S$. typhosa endotoxin before and on afebrile days 4 to 5 following convalescence from sandfly fever. The mean fever index during the convalescent phase was reduced only $19 \%$ from that of the control period. This paralleled the mean reduction of $21 \%$ resulting from similarly spaced injections of $S$. typhosa endotoxin in the normal control subjects.

\section{DISCUSSION}

Although several investigators have suggested that the clinical symptoms of typhoid fever may be mediated by circulating endotoxin $(6,13)$, few studies have evaluated critically those physiologic alterations that could be attributed specifically to its action. The most definitive studies deal with the phenomenon of acquired tolerance to the pyro- 
genic activity of endotoxin. If $S$. typhosa endotoxin participates in the pathogenesis of typhoid fever, tolerance to this endotoxin should develop during the course of illness. Moreover, since endotoxin from one bacterial species elicits tolerance to those from other species $(2,12)$, the phenomenon should not be restricted to $S$. typhosa endotoxin. To test this premise, Neva and Morgan assayed tolerance to the pyrogenic activity of $S$. typhosa and Shigella dysenteriae endotoxins in 22 patients during the afebrile convalescent days 4 to 6 following naturally acquired typhoid fever; significant tolerance (mean fever indexes, $50 \%$ below control levels) was reported (13). Tolerance, however, was assessed by comparing the fever index obtained following infection with that elicited in groups of control subjects. Individual variations in response to the same endotoxin within such control groups were considerable, and six of the 22 subjects convalescent from typhoid fever exhibited fever indexes higher than the mean of the control group; indeed, two subjects exhibited fever indexes higher than or equal to the maximal control responses. Previously, Heyman and Beeson reported that two subjects convalescent for 2 to 3 days from naturally acquired typhoid fever exhibited exaggerated febrile reactions, i.e., manifested decreased resistance to heatkilled $S$. typhosa (14). The evidence indicating development of tolerance to endotoxin during convalescence from typhoid fever could not be considered decisive.

Our findings, with each subject as his individual control, indicate unequivocally that a high degree of tolerance to $S$. typhosa and $E$. coli endotoxins is acquired during the convalescent phase of typhoid fever in man. Further studies are required to define specific differences in the degree of acquired tolerance to these homologous and heterologous endotoxins. The acquisition of this level of tolerance was not attributable to the residual effects of the initial testing with endotoxin. However, excluding the role of antibiotic (chloramphenicol) therapy in producing this endotoxin tolerance required special consideration. Essentially three problems were involved: 1 ) antibiotics alter normal host resistance to endotoxin (15$17)$; 2) antibiotics administered during typhoid fever might accentuate endotoxemia and lead to tolerance; and 3) shortening the course of illness might interrupt subsequent changes in hosttolerance mechanisms. The first possibility was virtually excluded by finding that subjects tested late in convalescence from typhoid fever, after tolerance had lapsed, acquired no significant tolerance to $S$. typhosa endotoxin after full dosages of chloramphenicol. The latter two possibilities cannot be excluded, but appear unlikely, as judged from the results of Neva and Morgan in untreated subjects. Also, one subject with overt illness in our series required no antibiotic therapy, but developed endotoxin tolerance comparable to that of subjects treated with chloramphenicol.

Two subjects in the present study failed to manifest overt illness after ingestion of $10^{6}$ and $10^{9}$ viable $S$. typhosa. The latter subject developed demonstrable S. typhosa bacteremia. Both subjects responded to $S$. typhosa endotoxin in a normal manner before and after the administration of viable organisms, i.e., no tolerance to endotoxin existed before or developed after ingestion of typhoid bacilli. From these observations, it appears that the mechanisms by which man can resist overt typhoid illness are not identical to those that confer resistance to endotoxin.

There was a striking parallelism between the altered endotoxin responsiveness of typhoid fever and that of tularemia, which is another illness induced by a bacterial species containing endotoxin ${ }^{10}$ and producing a similar clinical syndrome (20). Thus the acquisition of significant tolerance to endotoxin was demonstrable during the convalescent phase of tularemia induced either by intradermal or aerosol challenge. As in typhoid patients, this degree of tolerance was not ascribable to the residual effects of the initial testing with endotoxin, although the possible influence of streptomycin therapy remains unsettled. As in their responses to $S$. typhosa, subjects given $P$. tularensis could resist overt illness although fully capable of responding to endotoxin before and after challenge.

The present findings of acquired endotoxin tolerance following recovery from human typhoid

\footnotetext{
10 That $P$. tularensis contains endotoxin was demonstrated by isolation, with techniques similar to those used for preparing Shigella flexneri endotoxin (18), of a fraction possessing pyrogenic, Shwartzman-phenomenoninducing (preparatory and provocative), and lethal activity for rabbits (19).
} 
fever and tularemia are in apparent contrast with those reported in brucellosis. Enhanced, rather than tolerant, pyrogenic and subjective reactions were observed in subjects recovered from brucellosis when tested with Brucella endotoxin (21). The explanation for this divergence of results is uncertain, but may be related to the endotoxin preparations employed. Whereas the iv injection of $0.5 \mu \mathrm{g}$ of the endotoxins here employed consistently induced brisk febrile reactions in normal subjects, $100-\mu \mathrm{g}$ doses of the Brucella endotoxin employed by Abernathy and Spink (21) failed to elicit any febrile reactions. Moreover, the febrile reaction pattern produced by Brucella endotoxin in subjects recovered from brucellosis was markedly dissimilar from that produced by classical endotoxin preparations. The time of onset of fever averaged 6.1 hours, and the duration of the febrile reaction averaged 14 hours, in contrast to approximately 1 and 7 hours, respectively, with endotoxin preparations reported in our studies and by most investigators. Conceivably, the material employed as Brucella endotoxin was not primarily a pyrogen, but rather an antigen that produced fever on the basis of hypersensitivity in the sensitized human host. Studies with classical endotoxin preparations in convalescent brucellosis patients may resolve this discrepancy.

The significance of the acquisition of endotoxin tolerance during the convalescent phase of typhoid fever and tularemia is linked to two major considerations. 1) Do these data constitute specific evidence for the participation of circulating endotoxin during illness? 2) Does this reaction represent an important defense mechanism in recovery from typhoid fever [as initially postulated by Neva and Morgan (13)] and from tularemia? The first problem of endotoxin participation is difficult to resolve. Studies of a variety of infections in man show that the acquisition of endotoxin tolerance after infection develops only after typhoid, paratyphoid fever, and malaria $(13,14)$. In the current studies, no significant tolerance appeared after sandfly fever, a viral disease in which endotoxin presumably is not involved. Although it thus appears that fever and infection per se do not provoke endotoxin tolerance in man, it would be premature to conclude that the acquisition of endotoxin tolerance following typhoid fever and tularemia is due to endotoxemia. Indeed, no evidence is yet available that $P$. tularensis endotoxin is capable of mediating any of the observed tolerance to $S$. typhosa endotoxin. The findings of acquired tolerance, however, offer the strongest suggestive evidence thus far available supporting the concept that physiologically active quantities of circulating endotoxin contribute to the pathogenesis of these illnesses. The latter problem of the importance of endotoxin tolerance in the recovery process is currently under investigation.

\section{SUMMARY}

With each human subject as his own control, it was shown that a high degree of tolerance to the pyrogenic action of Salmonella typhosa and Escherichia coli endotoxins is acquired by afebrile days 3 to 12 following convalescence from induced typhoid fever. Such tolerance is not attributable to the residual effects of control testing with endotoxin, nor to the chloramphenicol employed for therapy. Significant tolerance to $S$. typhosa endotoxin developed by afebrile convalescent days 3 to 8 following human tularemia induced by either the intradermal or aerosol route. No significant tolerance to endotoxin developed in subjects given viable $S$. typhosa or Pasteurella tularensis who failed to manifest overt illness, or those given a viral disease, sandfly fever. Such findings support the premise that physiologically active quantities of circulating endotoxin contribute to the pathogenesis of typhoid fever and tularemia in man.

\section{ACKNOWLEDGMENTS}

The authors express their deepest appreciation to the volunteers who contributed so faithfully to these studies, to the house officers of the University of Maryland Hospital who assisted in care of these patients, and to the officials of the Maryland House of Correction for their generous cooperation and keen interest, without which these studies could not have been accomplished.

\section{REFERENCES}

1. Favorite, G. O., and H. R. Morgan. Effects produced by the intravenous injection in man of a toxic antigenic material derived from Eberthella typhosa: clinical, hematological, chemical and serological studies. J. clin. Invest. 1942, 21, 589.

2. Morgan, H. R. Resistance to the action of the endotoxins of enteric bacilli in man. J. clin. Invest. 1948, 27, 706. 
3. Beeson, P. B. Discussion of paper by W. W Spink on the significance of endotoxin in brucellosis: experimental and clinical studies. Trans. Ass. Amer. Phycns 1954, 67, 292.

4. Atkins, E. Pathogenesis of fever. Physiol. Rev. 1960, 40, 580.

5. Spink, W. W. The significance of endotoxin in brucellosis: experimental and clinical studies. Trans. Ass. Amer. Phycns 1954, 67, 283.

6. Mallory, F. B. A histological study of typhoid fever. J. exp. Med., 1898, 3, 611.

7. Greisman, S. E., T. E. Woodward, R. B. Hornick, and M. J. Snyder. Role of endotoxin in typhoid fever. Bull. N. Y. Acad. Med. 1961, 37, 493.

8. Hornick, R. B., T. E. Woodward, M. J. Snyder, L. J. Morse, and F. R. McCrumb, Jr. Studies on typhoid fever induced in volunteers. I. Clinical manifestations. In preparation.

9. Hornick, R. B., E. Gangarosa, J. T. Bulkeley, F. R. McCrumb, Jr., and T. E. Woodward. Studies on the immunoprophylaxis of tularemia. In preparation.

10. Webster, M. E., J. F. Sagin, M. Landy, and A. G. Johnson. Studies on the 0 antigen of Salmonella typhosa. I. Purification of the antigen. J. Immunol. 1955, 74, 455.

11. Boivin, A., and L. Mesrobeanu. Recherches sur les antigènes somatiques et sur les endotoxines des bactéries. I. Considérations générales et exposé des techniques utilisées. Rev. Immunol. (Paris) 1935, 1, 553.
12. Beeson, P. B. Tolerance to bacterial pyrogens. I. Factors influencing its development. J. exp. Med. 1947, 86, 29.

13. Neva, F. A., and H. R. Morgan. Tolerance to the action of endotoxins of enteric bacilli in patients convalescent from typhoid and paratyphoid fevers. J. Lab. clin. Med. 1950, 35, 911.

14. Heyman, A., and P. B. Beeson. Influence of various disease states upon the febrile response to intravenous injection of typhoid bacterial pyrogen. J. Lab. clin. Med. 1949, 34, 1400.

15. Miller, C. P., W. D. Hawk, and A. K. Boor. Protection against bacterial endotoxins by penicillin and its impurities. Science 1948, 107, 118.

16. Miller, C. P., and A. K. Boor. Protection of mice against lethal action of gonococcal endotoxin by penicillin. Proc. Soc. exp. Biol. (N. Y.) 1946, 61, 18.

17. Quan, S. F., T. H. Chen, and K. F. Meyer. Protective action of antibiotics against the toxin of Pasteurella pestis in mice. Proc. Soc. exp. Biol. (N. Y.) 1950, 75, 548.

18. Cluff, L. E. Immunochemical study of a bacterial endotoxin: Shigella flexneri type Z. J. exp. Med. 1954, 100, 391.

19. Cluff, L. E. Personal communication.

20. Cluff, L. E. Tularemia in Principles of Internal Medicine, 4th ed., T. R. Harrison, Ed. New York, McGraw-Hill, 1962, p. 963.

21. Abernathy, R. S., and W. W. Spink. Studies with Brucella endotoxin in humans: the significance of susceptibility to endotoxin in the pathogenesis of brucellosis. J. clin. Invest. 1958, 37, 219. 